\title{
Aplikasi Sistem Pembayaran Klinik Akupuntur Sehat Sejahtera Menggunakan Metode RAD
}

\author{
Puji Astuti ${ }^{1}$, Wina Yusnaeni ${ }^{2}$ \\ ${ }^{1}$ Program Studi Teknik Informatika, Sekolah Tinggi Manajemen Informatika dan Komputer Nusa \\ Mandiri, Kampus Nusa Mandiri Tower Jatiwaringin, Jln. Jatiwaringin Raya No. 02 RT. 08 RW 013 \\ Kelurahan Cipinang Melayu, Kecamatan Makasar, Jakarta Timur, Indonesia, 13620 \\ e-mail: ${ }^{1}$ puji.pat@ nusamandiri.ac.id
}

${ }^{2}$ Universitas Bina Sarana Informatika, Jln. Kramat Raya No. 98, Jakarta Pusat e-mail: ${ }^{2}$ wina.wyi@bsi.ac.id

Submitted Date: February $15^{\text {th }}, 2020$

Revised Date: June $08^{\text {th }}, 2021$
Reviewed Date: June $02^{\text {nd }}, 2021$

Accepted Date: June $15^{\text {th }}, 2021$

\begin{abstract}
Alternative medicine has long been known among the public as a treatment that can cure a variety of diseases. Types of alternative medicine are many types of one that we know in the form of acupuncture treatment. Acupuncture treatment in Indonesia is not new and there are many people who do treatment in this way, even it has been fairly official because it is already a clinic - clinics scattered throughout Indonesia. One of the acupuncture clinics located at Jl. Lelel 5 Pamulang Timur, South Tangerang. At Klinik Akupuntur Sehat Sejahtera offers a variety of acupuncture packages, only in the system used in this clinic is still manual ranging from recording patient data, drug data to payment transactions. With that reason, a solution is needed that can be used to facilitate data collection and also more efficient in data storage, namely with desktop application information system. By using rad research method as the flow of the system. The results obtained from RAD methods and applications with JAVA can help admins in inputting patient data, drug data and payment transactions at healthy acupuncture clinics in east Pamulang.
\end{abstract}

Keywords: Application; information system; RAD

\begin{abstract}
Abstrak
Pengobatan alternatif sudah sejak lama dikenal di kalangan masyarakat sebagai pengobatan yang bisa menyembuhkan berbagai macam penyakit. Jenis pengobatan alternatif banyak jenisnya salah satu yang kita kenal berupa pengobatan akupuntur. Pengobatan akupuntur di indonesia bukan hal yang baru dan sudah banyak masyarakat yang melakukan pengobatan dengan cara ini, bahkan sudah terbilang resmi karena sudah berupa klinik - klinik yang tersebar di seluruh indonesia. Salah satu klinik akupuntur yang ada berada di Jl. Lelel 5 Pamulang Timur, Tangerang Selatan. Di Klinik Akupuntur Sehat Sejahtera menawarkan berbagai macam paket akupuntur, hanya saja dalam sistem yang digunakan di klinik ini masih bersifat manual mulai dari pencatatan data pasien, data obat sampai dengan transaksi pembayaran. Dengan alasan tersebut maka diperlukan solusi yang bisa digunakan untuk mempermudah pendataan dan juga lebih efisien dalam penyimpanan data yaitu dengan sistem informasi aplikasi desktop . Dengan menggunakan metode penelitian RAD sebagai alur sistemnya. Hasil yang didapat dari metode RAD dan aplikasi dengan JAVA dapat membantu admin dalam penginputan data pasien, data obat dan transaksi pembayaran pada klinik akupuntur sehat sejahtera pamulang timur.
\end{abstract}

Kata kunci : Aplikasi; sistem informasi; RAD 


\section{Pendahuluan}

Pengobatan alternatif akupuntur merupakan salah satu jenis pengobatan yang kita ketahui, pengobatan alternatif akupuntur ini memberikan manfaat yang banyak bagi kesehatan serta bisa juga sebagai pengobatan untuk mengobati berbagai penyakit. Akupuntur sangat populer sebagai metode pengobatan alternatif untuk penyembuhan penyakit. Saat ini klinik memang lebih fleksibel dibandingkan dengan RS. Klinikpun sangat efisien dalam menarik minat konsumen serta memudahkan dalam pelayanan (Rahmawati, Eva, Hertiana, Hylenarti, Mufida, Elly, 2020). Akupuntur dapat memunculkan rasa analgesik, rasa analgesik dapat diperlukan untuk mengatasi rasa sakit disertai rasa nyeri seperti migren (D erliantini, Ni Gusti A.Kd, Djuminten, 2014).

Klinik akupuntur adalah balai pengobatan alternatif dengan menawarkan pengobatan akupuntur yang sudah banyak tersebar di indonesia. Salah satunya klinik akupuntur yang ada di wilayah pamulang timur, Tangerang Selatan. Sistem yang digunakan dalam memproses data klinik masih ada yang dilakukan masih manual. Ketika pasien melakukan pendaftaran maka bagian kasir akan mencari dari catatan atau mencatat ulang data pasien karena kesulitan ketika mencari catatan sebelumnya. Penyebab sulitnya dalam pencarian data pasien pada saat pendaftaran umumnya terjadi akibat dari pelayanan yang kurang efektif terutama pada klinik yang menggunakan sistem komputerisasi (Sumardi, Lina, \& Parwatiningtyas, 2020). Rekam medis adalah pemberkasan yang berisikan catatan dan dokumentasi tentang data diri pasien, pemeriksaan, data obat, tindakan, dan pelayanan yang telah diberikan untuk pasien (Hardinata, 2015). Kesulitan dalam pencarian data pasien saat melakukan pendaftaran kebanyakan terjadi akibat dari sistem pelayanan yang kurang efektif terutama pada klinik yang belum menggunakan sistem terkomputerisasi (Sumardi et al., 2020).

Pada saat ini, ilmu pengetahuan dan teknologi telah mengalami kemajuan yang signifikan, Semuanya dikembangkan untuk memudahkan bagi manusia dalam melakukan tugas dan tanggung jawabnya (Khotimah \& Iriani, 2014). Dengan kemajuan teknologi saat ini seharusnya penggunaan sistem informasi bisa diterapkan, dengan memanfaatkan perkembangan teknologi saat ini bisa memudahkan klinik dalam pengolahan data juga dapat membatu dalam pencarian data penyimpanan data menjadi lebih cepat dan efektif. Dengan masalah yang terjadi pada klinik akuputur, karena pemberkasan yang masih dilakukan dengan pencatatan pada buku besar maka penelitian ini dilakukan untuk membuat sistem infromasi klinik akupuntur dengan metode pengambangan sistem menggunakan metode RAD. Merancang sistem informasi dengan menggunakan pemograman berbasis objek yaitu JAVA. Manfaat dari penelitian ini memberikan alternatif yang dapat membantu sistem yang saat ini digunakan menjadi sistema yang lebih baik dan efisien.

\section{Metode Penelitian}

Data diperoleh dengan menggunakan metode pengumpulan data. Berikut ini teknik yang digunakan:

1. Observasi, dengan cara melakukan pengamatan langsung di klinik akupuntur yang ada diwilayah Pamulang, Tangerang Selatan. Dengan hal ini maka diketahui bahwa sistem disini masih menggunakan sistem manual.

2. Studi Pustaka, metode pengumpulan data didapat dari jurnal, dan modul yang berkaitan dengan tema yang dibahas.

\section{Metode Pengembangan Perangkat Lunak RAD yaitu \\ RAD (Rapid Application Development)} adalah metodologi pengembangan sistem yang dilakukan dengan menggunakan pendekatan yang beriontasi objek, RAD juga di sebut sebagai Model prroses dalam perkembangan software sekuensial linier yang menggambarkan siklus perkembangan pendek (Habibi, Roni, 2019). Tiga Tahapan dari RAD adalah (Aswati \& Siagian, 2016):

1. Rencana kebutuhan atau Requirement Planning: menentukan kebutuhan apa saja yang diperlukan dalam suatu sistem yang bisa ditentukan oleh user dan analis.

2. Proses Desain Sistem atau Design System : proses user dalam proses desain yang sesuai antara user dan analis. Tools yang digunakan dalam proses desain salah satunya adalah menggunakan UML.

3. Implementasi atau Implementation: tahap ini adalah di mana implementasi desain yang telah dilakukan ke dalam bentuk koding oleh programmer. Yang selanjutkan aplikasi akan dilakukan pengujian oleh user apakah ada 
kesalahan atau error dalam program, disini user bisa memberikan pendapatnya kekurangan dari suatu aplikasi sehingga programmer akan memperbaiki error yang terjadi sesuai kesepakatan user dan analis.

Diagram alur RAD digambarkan seperti di bawah ini:

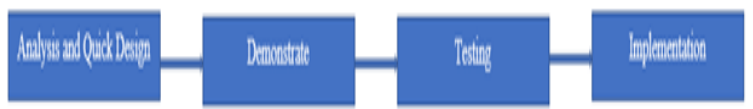

Sumber :(Habibi, Roni, 2019)

Gambar 1. Langkah Penerapan RAD

\section{Analisa}

Dalam pembuatan aplikasi sistem pembayaran klinik akupuntur di wilayah pamulang tangerang selatan ini, dilihat dari analisis yang terjadi pada klinik tersebut masih menggunakan proses manual, dalam hal pendaftaran, pembayaran bahkan sampai ke laporannya.

\subsection{Requirement Planning}

Analisa kebutuhan yang ada pada sistem ini adalah user yaitu admin dimana Admin dapat masuk dengan hak akses username dan password yang sudah ada. Admin dapat mengakses data pasien, data dokter, data obat, data tindakan, data transaksi dan admin juga mencetak struk transaksi pembayaran. Berikut gambar komposisi dari sistem aplikasi klinik akupuntur.

\subsection{Design System}

a. Database

Alat desain yang membantu dalam mengelompokkan data pada suatu proyek ke bentuk entitas-entitas dan menentukan relasi antara entitas (Simarmata, 2007).

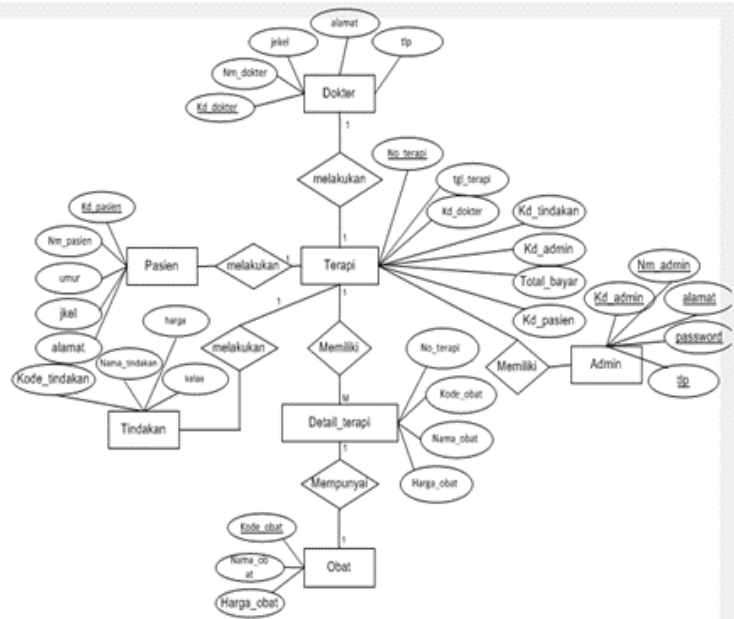

Gambar 2. Entity Relationship Diagram Sistem pembayaran Klinik Akupuntur

b. Sistem

Desain sistem menggunakan tools system yaitu UML berupa use case ,activity diagram, Class Diagram dan sequence diagram.

1. Use Case Proses Admin

Use Case diagram bertujuan dalam penggambaran analisis kebutuhan dari sutau sistem secara fungsional dan interaksi diantara actor (Munawar, 2018).

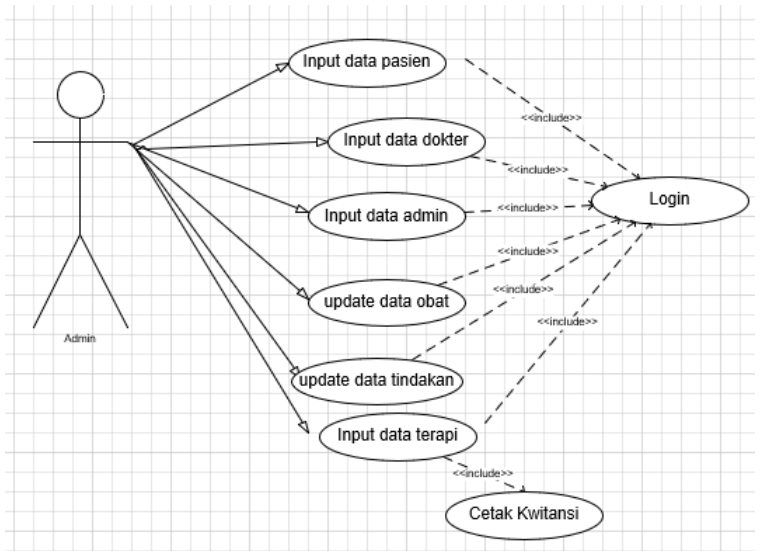

Gambar 3. Use Case Proses Admin

Pada proses gambar 3 admin memproses semua kegiatan yang ada didalam klinik akupuntur. Dimulai dari input data pasien, sampai input data transaksi dan pembayaran admin yang melakukan sistem di dalamnya.

2. Activity Diagram Login

Diagram aktivitas digunakan untuk menampilkan aliran kerja dari aktivitas 
sebuah sistem atau juga menu yang terdapat pada perangkat lunak (Rosa, Shalahuddin, 2014).

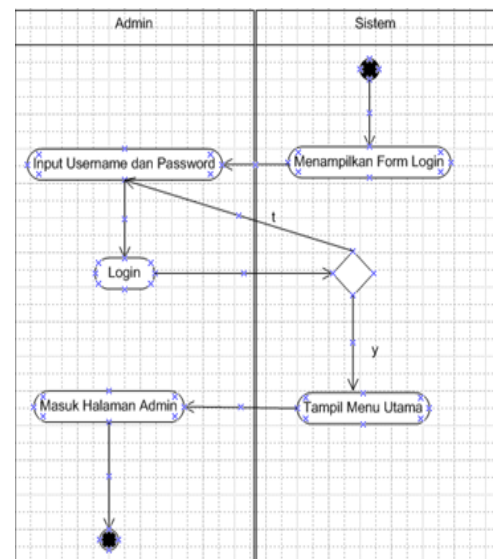

Gambar 5. Activity Diagram Login

Dilihat di gambar 5, aktivitas dalam melakukan login dengan memasukkan username dan password dengan benar jika salah maka akan kembali ke menu login untuk diulang.

3. Activity Diagram Master

Activity diagram menu master

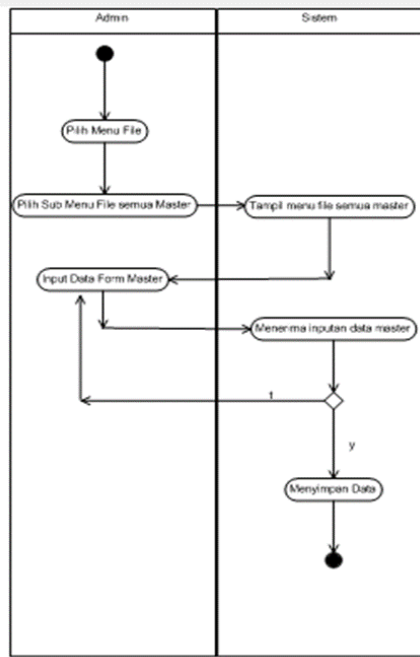

Gambar 6. Activity Diagram master

Pada gambar 6. Urutan langkah aktivitas dalam memilih pilihan menu pada tampilan program. Diawali dengan menggunakan start dan pilihan menu selanjutnya pemprosesan oleh sistem untuk menmpilkan menu yang dipilih.

4. Activity Diagram Terapi

Activity Diagram terapi merupakan alur activity transaksi pembayaran.

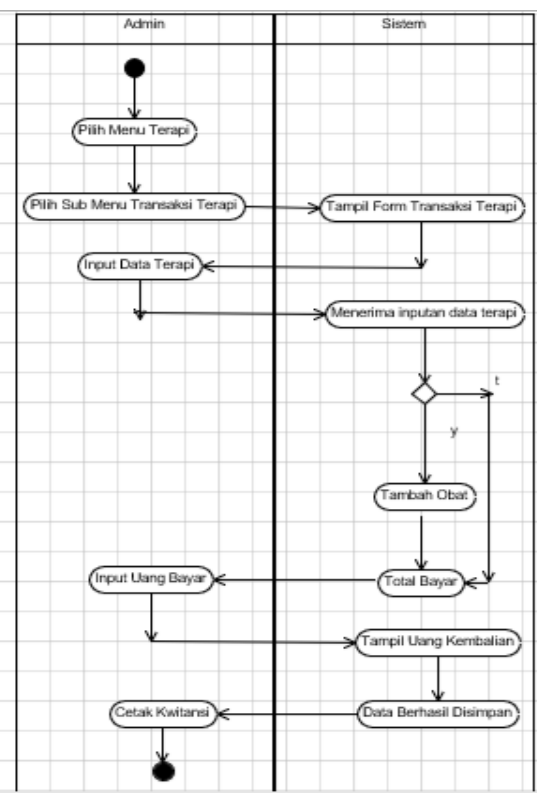

Gambar 7. Activity Diagram Terapi

Gambar 7 di mana kegiatan input data terapi dan di proses oleh sistem dalam penyimpanan datanya. Selanjutnya adanya proses perhitungan total bayar untuk menghasilkan bukti pembayaran.

5. Class diagram Sistem Pembayaran Klinik akupuntur

Rancangan database dengan menggunakan class diagram terdapat pada gambar 8 . 


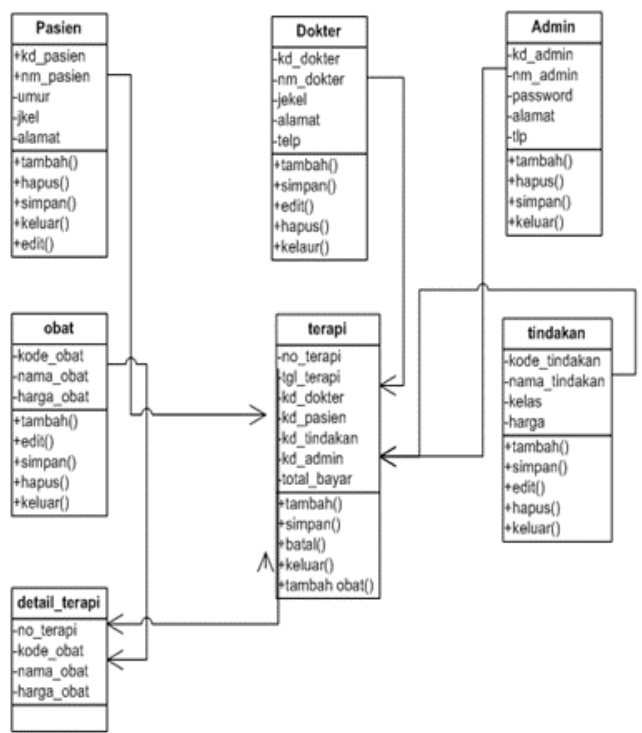

Gambar 8. Class Diagram Sistem Pembayaran Klinik akupuntur

Yang tertera pada gambar 8. Penggambaran diagram class dimana terdapat elemen sistem. seperti class pasien, dokter dst.

6. Sequence Diagram Login

Alur login menggunakan sequence diagram pada gambar 9 .

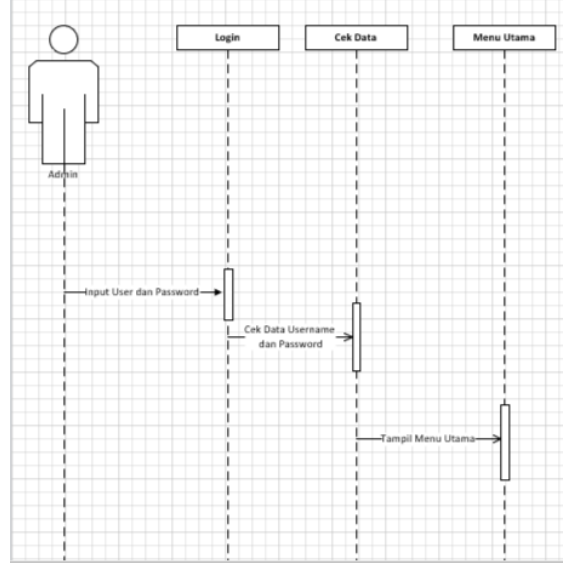

Gambar 9. Class Diagram Login

\subsection{Implemention}

Tahapan selanjutnya adalah tahap implementasi dimana pada tahapan ini aplikasi sistem klinik akupuntur dibangun.

1. Halaman Login Admin

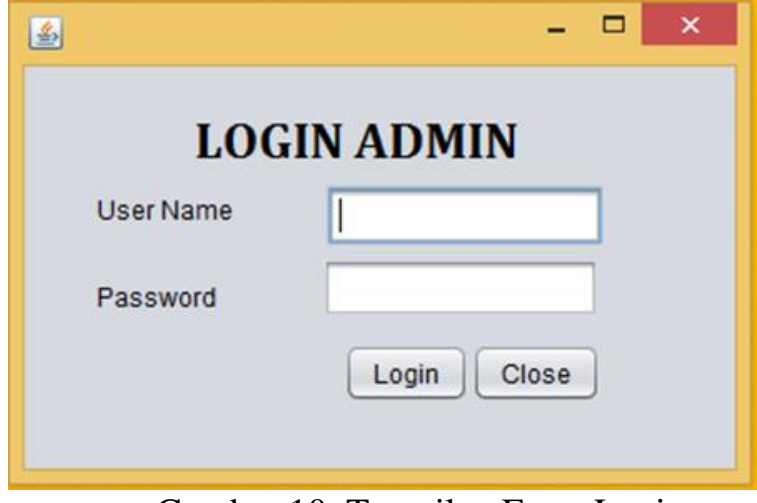

Gambar 10. Tampilan Form Login

Halaman login admin dimulai dengan admin terlebih dahulu menginput username dan password untuk bisa masuk ke menu utama. Seandainya inputan yang diberikan salah maka akan muncul pesan dan akan kembali ke login kosong untuk input kembali.

2. Halaman Menu Utama

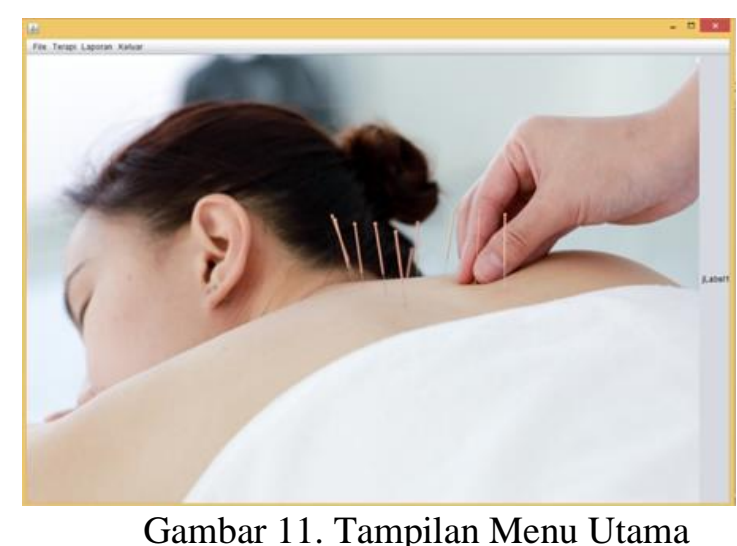

Menu utama ini berisi menu-menu dan submenu yang ada di aplikasi sistem klinik akupuntur. Pilihan menu yang di lihat mulai dari menu file terdiri dari pasien, obat ,dan paket kemudian ada terapi untuk menu transaksi pengolahan data dengan menghasilkan cetak data pembayaran.

3. Halaman Form Pasien 


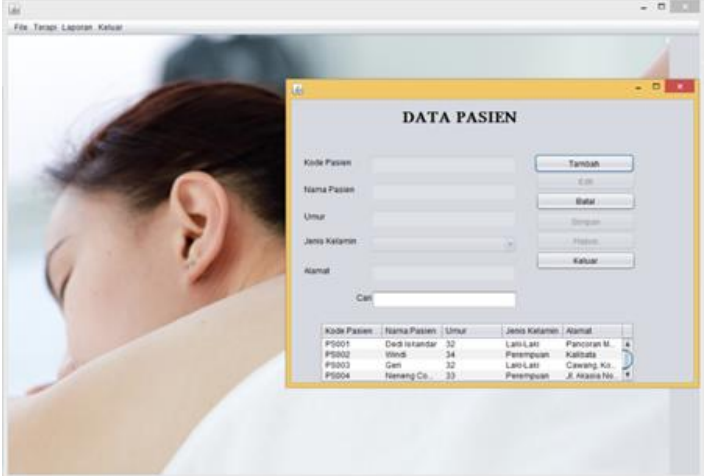

Gambar 12. Tampilan form Pasien

Berisikan data pasien yang baru mendaftar di mana data tersebut diinput oleh admin. Dengan pilihan untuk menambah pasien baru, untuk merubah, menghapus dan keluar dari form.

\section{Halaman Form Dokter}

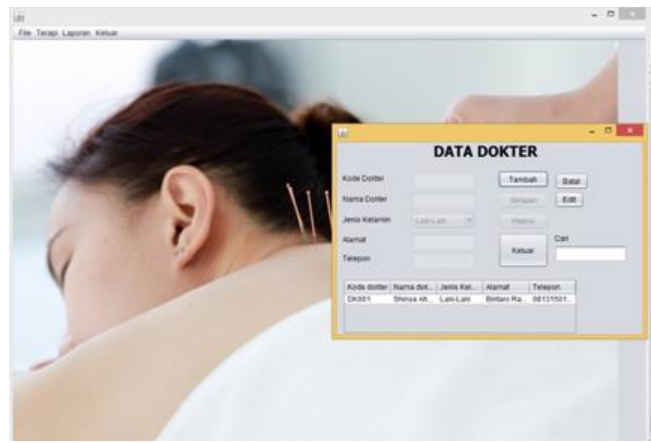

Gambar 13. Tampilan Form Dokter

Berisikan data Dokter yang diinput oleh admin. Di from dokter berisi informasi dokter akunpur yang beroperasi di klinik.

\section{Halaman Form Admin}

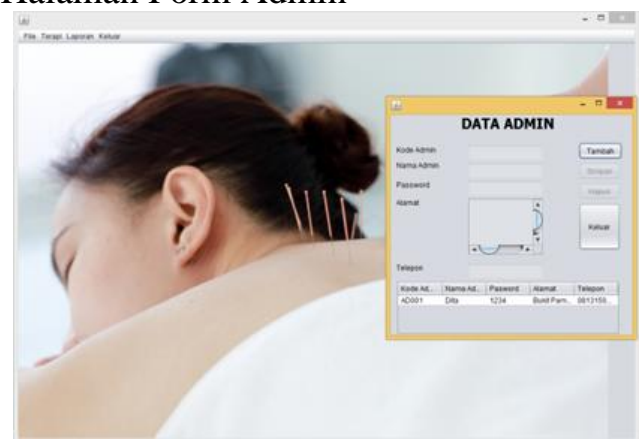

Gambar 14. Tampilan Form Admin

Berisikan data Admin yang diinput oleh admin. Form admin bertujuan dalam pemberian hak akses pada staf yang bisa menggunkan aplikasi ini.
6. Halaman Form Obat

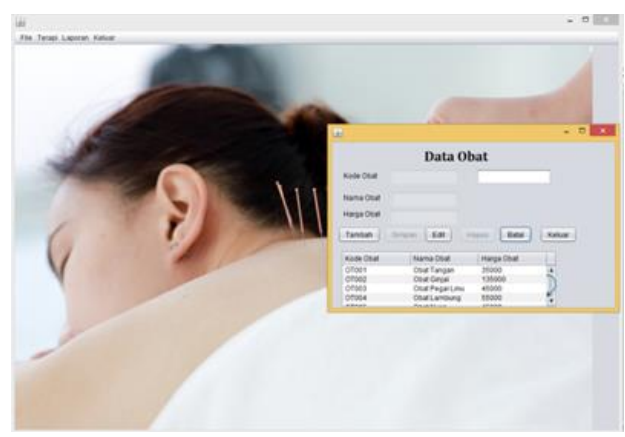

Gambar 15. Tampilan Form Obat

Berisikan data Obat yang diinput oleh admin. Berisi info obat yang digunakan dan yang diberikan kepada pasien.

7. Halaman Form Tindakan

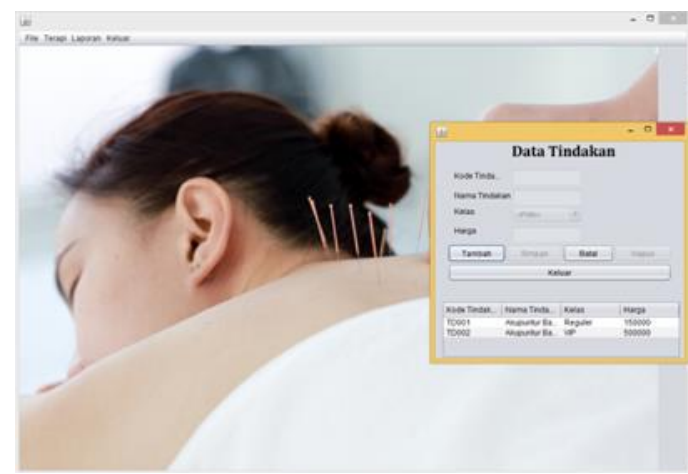

Gambar 16. Tampilan Form Tindakan

Form Tindakan Dokter dimana Admin menambahkan data tindakan dokter. Berisi info akan tindakan yang dilakukan oleh dokter yang dapat digunakan info biaya dari tindakan yang dilakukan.

8. Halaman Form Terapi

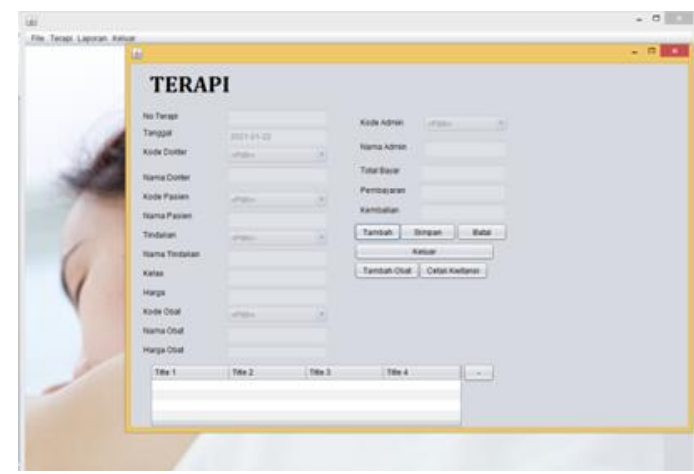

Gambar 17. Tampilan Form Terapi 
Admin dapat memproses transaksi yang telah dilakukan oleh pasien untuk melakukan pembayaran. Di form ini bukti transaksi di cetak sebagai pelunasan bukti bayar tindakan dan obat yang diberikan terhadap pasien.

\section{Pengujian Program}

Untuk pengujian Program dilakukan untuk mengetahui apakah program bekerja sesuai dengan yang diinginkan atau ada error yang terjadi ketika pengujian dilakukan. Pengujian dilakukan dari history transaski yang terjadi pada sistem aplikasi pembayaran klinik akupuntur.

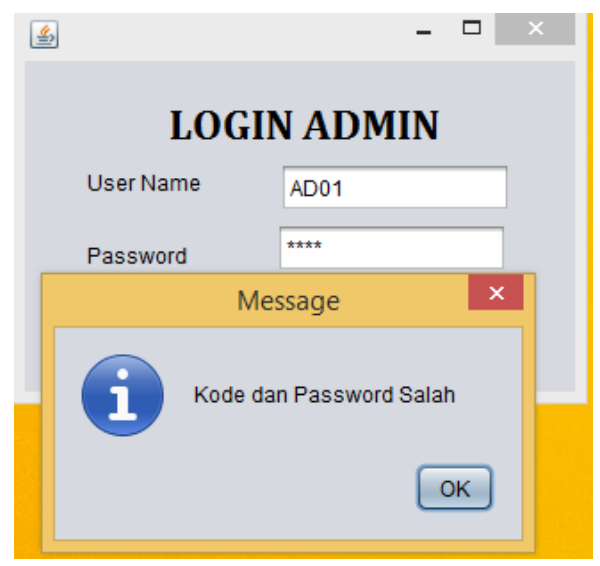

Gambar 18. Hasil pengujian terhadap kesalahan input pada login admin

Pada form terapi dilakukan inputan data pasien, tindakan serta sampai total pembayaran yang dilakukan jika data terisi maka transaksi bisa diproses. Dan bukti pembayaran akan tampil sebagai bukti pembayaran lunas.

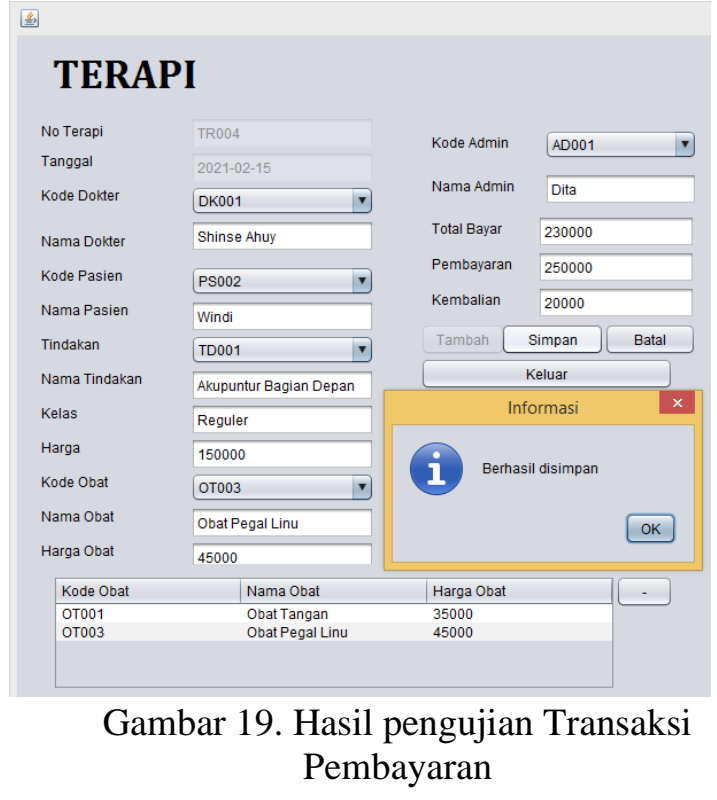

\section{Kesimpulan}

Dalam penelitian ini menghasilkan beberapa kesimpulan di antaranya:

a. Mempermudah dalam pengolahan data,

b. Mengurangi adanya duplikasi data,

c. Menyimpan data dalam jumlah banyak karena hanya admin yang dapat mengakses sistem aplikasi klinik akupuntur.

\section{Saran}

Dalam aplikasi sistem klinik akupuntur ini dapat dibuat lebih baik lagi mengikuti perkembangan teknologi yang ada saat ini. Dapat dibuatkan aplikasi sistem pendafataran pasien dengan mobile sehingga pasien datang langsung menyertakan bukti nomor pendaftarannya. Serta perlu adanya pengecekan secara berkala agar data dapat tersimpan dengan aman..

\section{Referesi}

Aswati, S., \& Siagian, Y. (2016). Model Rapid Application Development Dalam Rancang Bangun Sistem Informasi Pemasaran Rumah (Studi Kasus: Perum Perumnas Cabang Medan. Jurnal Sesindo, 317-324.

Derliantini, Ni Gusti A.Kd, Djuminten, H. P. (2014). Pengaruh Akupuntur Terhadap Migren Pada Pasien Di Klinik Akupuntur Community Development Bethesda Yogyakarta.

Habibi, Roni, \& R. A. (2019). Tutorial dan Penjelasan Aplikasi E-Office Berbasis Web 
Menggunakan Metode RAD. (E. . (Robi Habibi, Ed.). Bandung: Informatics Engineering.

Hardinata, N. (2015). Analisis Dan Perancangan Sistem Informasi Rekam Medis Pada Puskesmas Kecamatan X. Teknologi Informasi, 1(1), 6-8. Retrieved from https://www.academia.edu/10160144/SIST EM_INFORMASI_REKAM_MEDIS

Khotimah, A. H., \& Iriani, S. (2014). Sistem Informasi Nilai Siswa Pada Madrasah Tsanawiyah (Mts) Al Muhajirin Kalak Donorojo. IJNS-Indonesian Journal on Networking and Security, 3(1), 2354-6654. Retrieved from http://ijns.org

Munawar. (2018). Analisis Perancangan Berbasis Objek dengan UML. Bandung: Informatika.

Rahmawati, Eva, Hertiana, Hylenarti, Mufida, Elly, R. (2020). Rancang Bangun Sistem Informasi Pelayanan Medis Pada Klinik Dr. Afriyanti Menggunakan Model Waterfall. Jurnal Teknik Komputer AMIK BSI2, VI(1), 1-10. https://doi.org/10.31294/jtk.v4i2

Rosa, Shalahuddin, M. (2014). Rekayasa Perangkat Lunak Terstruktur dan Berorientasi Objek. Bandung: Informatika.

Simarmata, J. dan I. P. (2007). Basis Data. Yogyakarta: CV. Andi Offset.

Sumardi, S., Lina, I. M., \& Parwatiningtyas, D. (2020). Sistem Administrasi Klinik Harapan Ibu Berbasis Java Netbeans. Jurnal Riset Dan Aplikasi Mahasiswa Informatika (JRAMI), 1(03), 361-367. https://doi.org/10.30998/jrami.v1i03.360 